\title{
Employee Motivation in Private Schools of Birgunj Metropolitan City
}

\author{
Lalan Dwibedi \\ Lecturer \\ Faculty of Management, Thakur Ram Multiple, Campus, Birgunj, Tribhuvan University, Nepal \\ Email: dwivedylalan@gmail.com
}

DOI: https://doi.org/10.3126/dristikon.v10i1.34553

\begin{abstract}
The paper aims to find out which motivational factors can effectively increase employee motivation, to know whether the delivered incentives are sufficient or not and also to know effect of incentives in their performance. Motivation and its influence on organizational performance has always remained highly researched area and have gone through many discussions and repetitions. In this research both exploratory and descriptive research design used to explore employee motivation issues in schools of Birgunj Metropolitan city. Data was collected through Questionnaire and content analysis. It is revealed that motivating factors and motivational packages has positive impact on employee motivation in private schools. The responses of this paper were analyzed and found that monetary and non-monetary both incentives are active tools to motivate workforce. Good salary and allowances have been used as monetary motivators, while, good working environment, freedom to work and recognition as non-monetary motivator. This study has recommended that promotion system of the career development is desired to satisfy and motivate the employee. Moreover, the work appreciation should craft the feeling that they are value for the organization.
\end{abstract}

Keywords: motivation, incentives, career development, performance, satisfaction, dissatisfaction, employees

\section{Introduction}

\section{Background}

Education is the foundation of any developed, underdeveloped or developing country. The importance of education in the overall development of human beings cannot be exaggerated. The teacher as an employee is the one who interprets educational philosophy and objectives into practical knowledge and skills base and transfer those to the students. Alumode (2005) maintained that education is the vehicle for rapid national development as it raises the young ones who will effectively manage the economy. The extent to which the values of education are achieved however depends on the activities or practices of administrators who organize, coordinate, direct and motivate employees in order to achieve desired organizational goals and objectives.

A person's efficiency depends on the level of ability to do a certain work and the willingness to do the work. The level of ability to do a certain work can be acquired by 
education and training, but the willingness to do the work can be created by motivation. There are so many motives and they are changing with time and are invisible and directed towards certain goals. Therefore, motivation in this study pivots on how satisfied or dissatisfied teachers are with their job dispositions in school.

According to Webster's New Collegiate Dictionary, a motive is "something a need or desire that causes a person to act". "Motivate, in turn, means "to provide with a motive," and motivation is defined as "the act or process of motivating". Consequently, motivation is the performance or procedure of presenting an intention that origin a person to capture some accomplishment (Shanks). According to Butkus and Green (1999), motivation is derived from the word "motivate", means to move, push or influence to proceed for fulfilling a want. Motivation is an integral part of management process. An enterprise may have the best of material, machines and other means of production but all these resources are meaningless so long as they are not utilized by properly motivated people. According to Omebe (2005) motivation can be defined as those conditions such as praises, rewards, promotion, among others that arouse the interest of teachers in performing their duties deligently.

Bartol and Martin (1998) describe motivation as a power that strengthens behavior, gives route to behavior, and triggers the tendency to continue. This explanation identifies that in order to attain assured targets; individuals must be satisfactorily energetic and be clear about their destinations. In view of Bedeian (1993) it is an internal drives to satisfy an unsatisfied need and the will to accomplish. Motivation is a procedure that initiates through a physiological or psychological want that stimulates a performance that is intended at an objective. It is the concluding product of interface among personality behavior and organizational distinctiveness. Similarly, it symbolizes those psychological procedures that foundations the stimulation, route, and determination of deliberate actions that are target oriented (Farhad et al., 2011).

Furthermore, motivation is a progression of moving and supporting goal-directed behavior (Chowdhury, 2007). Again, it is an internal strength that drives individuals to pull off personal and organizational goals (Reena et. al., 2009).

Motivation is a set of courses concerned with a kid of strength that boosts performance and directs towards accomplishing some definite targets (Kalimullah et al., 2010). According to Barron (1983), it is an accrual of diverse routes which manipulate and express our activities to attain some particular ambitions. Porter and Miles (1974) proved that the motivation boosts expresses and continues conduct. Letter et al. (2003), the motivation of an individual envelops all the motives for which he selects to operate in a definite approach.

Among financial, economic and human resources, the latest are more essential and have the capability to endow a company with competitive edge as compared to others (Rizwan et al., 2010). Employee Performance fundamentally depend on many factors like performance appraisals, employee motivation, Employee satisfaction, compensation, training and 
development, job security, Organizational structure and other, but the area of study is more focused on employee motivation as this factor highly influence the performance of employees.

\section{Research Problem}

Motivational tools and packages are the best way of transmitting educational policy into action by motivating teachers/employees. It seems that most teachers in schools are not devoted to their duties in school which could be as a result of poor motivating factors and packages adopted by the schools. Most of school's management falls short of the preferred aptitude and skills of motivation. In this situation where the employees are not motivated, there is bound to be disorder and misunderstanding in schools. A motivated employee is responsive of the define goals and objectives they must achieve; therefore, they direct its efforts in that direction. Motivation formulates an organization more successful because motivated employees are constantly looking for improved practices to do a work, so it is essential for organizations to encourage motivation of their employees. Getting best work from their employees even in strenuous circumstances, it is one of the most stable and greasy challenges and this can be made possible through motivating them. However, the problem of this study put in question form is: "what is the motivational practice for teachers/employees effectiveness in private schools of birgunj metropolitan city? Could ownership of schools influence the motivational factors and motivating packages adopted by management for teachers/employees? This is also the research gaps in this study.

\section{Research Objective}

The main objective of the study is to assess the motivational factors that can increase employee motivation and promote innovation within the private schools of Birgunj Metropolitan city, Parsa Nepal. The specific objectives of the study are:

- To explore insight concept of employee's motivation and requirement of the study.

- To identify the factors and incentives that should implemented or eliminated to motivate the employees/teachers.

- To examine the factors that lead to effective job performance, high morale and motivation of the employees.

\section{Significance of the Research Paper}

The studies strive for to explore possible strategies for improving employee's motivation and relation with management. This research broadened understanding of the various factors influencing performance of teachers/ employees. It also developed an understanding to the management on how motivation contributed positively towards the performance of employees. It is also important to policy makers and administrators as it identifies the major strategies to modify the behavior of teaching staff towards their 
performance. However, today, private schools are also facing challenges in employee retention. Acknowledging the important role of employees and the huge influence they bring towards organizational effectiveness, private schools are trying to retain employees by applying different motivational factors, tools and packages and a healthier workplace. Unless and until the employees are motivated and satisfied, an organization cannot foster to success. Motivated employees are more innovative as they are always looking for better ways to perform their teaching learning activities.

\section{Limitations of the Study}

Like other empirical studies, this study had also some limitations, nevertheless this research attempts to follow valid and reliable research procedures, using both exploratory and descriptive research design to gather data from a sample with a high response rate. However, the study was primarily focused in general sphere of factors, packages and practice of motivation in private school. This study could not include many other interesting themes and prospective of motivation in the particular topic. Due to the time and cost constraint, it was necessary to limit the study to private schools in a single area of Nepal. Thus, the study population limited to Birgunj metropolitan City. So the results may not be generalized to all parts of Nepal.

\section{Literature Review}

Motivation is derived from the word 'motive' which means the latest power in a person which impels him to do a work. Motivation is the process of steering a person's inner drives and actions towards certain goals and committing his energies to achieve these goals. It involves a chain reaction starting with felt needs, resulting in motives which give rise to tension which census action towards goals. It is the process of stimulating people to strive willingly towards the achievement of organizational goals. Motivation may be defined as the work a manager performs in order to induce subordinates to act on the desired manner by satisfying their needs and desires.

Shadare et al. (2009), Employee motivation is one of the policies of managers to increase effectual job management amongst employees in organizations. A motivated employee is responsive of the definite goals and objectives he/she must achieve; therefore he/she directs its efforts in that direction. Similarly, Rutherford (1990) reported that motivation formulates an organization more successful because provoked employees are constantly looking for improved practices to do a work, so it is essential for organizations to persuade motivation of their employees.

Some of the research suggested that money is not as important as it seemed to be, many companies tried to implement monetary incentives as their main tool to motivate employees. Performance related pay became the new mantra that was used questionably by plenty of 
organizations (Frey \& Osterloh, 2002). The literature on a subject of motivation shows that there are several other ways to motivate employees. The most well-known and often cited theories can be divided into two categories: content theories and process theories. The first group is focused on what motivate people. It is represented by authors such as Maslow, McClelland and Herzberg. The second group tries to find out how motivation occurs. Vroom, Adams, Locke and Latham created the most influential process theories.

Some authors (Oldman \& Hackman, 2010; Lawyer, 1969) found that job design plays important role in shaping employees behavior while others (Roche \& MacKinnon, 1970; Allender \& Allender, 2006; Mayfield \& Kopf, 1998) suggest that leadership style and freedom given to employees are crucial in motivating employees. Another group of researchers try to prove that recognition can be used to motivate people to perform well. The importance of motivating factors might vary among particular groups of people. However, there are several motivating factors that are very often ranked high positions. Interesting work, full appreciation of work done, feeling of being well informed and involved, and good incentives are the factors that received high rates in many research (Lindahl, 1949; Kovach, 1980, 1987, 1995; Fischer \& Yuan, 1998; Kinnear \& Sutherland, 2000).

The most common factors that are taken into consideration come from two categories: monetary and non-monetary incentives. Rynes, Gerhart and Minette (2004) in their study on the importance of pay in employee motivation found that money is not a motivating factor for every person and not in every circumstance. However, it is an important factor for most people. That might lead to an underestimation of monetary rewards as one of the motivating factors in job settings.

There is a large group of researchers who neglect the fact that money is a good motivator. For example, McClelland (1968) writes that "money isn't as potent a motivating force as theory and common sense suggest it should be". The result that supports McClelland words come from McKinsey Quarterly survey conducted in June 2009 (Dewhurst, Guthridge, $\&$ Mohr, 2009). Responses received from 1,047 executives, managers and employees around the world showed that three non-cash motivators (praise from managers, leadership attention, a chance to lead projects or task forces) are more effective motivators than the three highest-rated financial incentives (cash bonuses, increased base pay, and stock options).

Professors at Massachusetts Institute of Technology and University of California, Santa Barbara, published a paper titled "Incentives and Creativity: Evidence from the Academic Life Sciences" indicating that long term rewards rather than short term rewards helped to motivate scientists in their work and to promote overall greater creativity. The application of this study suggests that short term rewards, that are common in many businesses, may truncate motivation and hinder innovation (Azoulay, Graff- Zivin \& Manso 2010). 
Mullins (2006) suggests that motivation is one of the key ingredients in employee performance and productivity. Even when people have clear work objectives, the right skills and a supportive work environment, they would not get the job done without sufficient motivation to achieve those work objectives. In a study, the authors aimed at examining 'whether monetary rewards can reduce failures to act on cued task goal'. With a research sample comprising of 36 undergraduates, the authors experimented to see how quick their respondents reacted to specific tasks when given a range of monetary rewards ranging from low to high rewards. The studies found out that giving relatively high monetary rewards, led to 'overall faster responses' to the specific tasks given to respondents. Their finding is consistent with other studies which noted that relatively high monetary rewards may function as a catalyst for enhanced effort or determination by employees to perform well.

Employee motivation, at times, can be an intangible mission for schools due to the multiplicity of incentives that can influence employees to do their best work. Furthermore, short-term financial incentives are often seen as mandatory to foster motivation and are generally viewed very positively by employees in the workplace. However, research has indicated that there are other factors that can significantly influence motivation and lead to innovation. The comprehensive understanding of motivation lies in the need-drive-incentive sequence or cycle. The basic process involves needs (deficiencies), which set drives in motion (deficiencies with direction) accomplish incentives (anything which alleviates a need and reduces a drive).

\section{Methods and Materials}

In this research both exploratory and descriptive research design used to explore employee motivation issues in schools of Birgunj Metropolitan city. The study depends on primary data collected from the employees/teachers and some secondary data collected through content analysis. The primary data was collected through the field survey using questionnaires and interview. The first part of the study is concerned with gathering preliminary information about the respondents. The second part focused on assessing employee motivation using different variables. A random sampling technique was used to form a sampling for this study. A total of 93 private secondary schools are working in Birgunj Metropolitan city. Among them 20 schools were randomly selected as sample for the study representing $21.50 \%$ of the total population. A sum of 200 questionnaire forms was sent to the teachers working at different level in sampled schools of which 197 questionnaires were returned with a response of $98.5 \%$ out of them 194 questionnaire forms were properly completed and valid for analysis (97.00\%). The questionnaires comprised of both close-ended and open-ended questions. These formed the basis of the analysis of the study. The questionnaire and the interview have been done with all the sampled teachers' staff of selected schools. 


\section{Results and Discussion}

\section{Table 1}

Preliminary Information Regarding the Sample

\begin{tabular}{lrr}
\hline & Frequency & Percentage (\%) \\
\hline Male & 89 & 45.88 \\
Female & 105 & 54.12 \\
Total & 194 & 100 \\
Age & & \\
20-30 & 92 & 47.42 \\
$31-40$ & 62 & 31.96 \\
41-50 & 25 & 12.89 \\
Above 50 & 15 & 07.73 \\
Total & 194 & 100 \\
Educational level & & \\
SLC & 35 & 18.04 \\
Certificate Level & 45 & 23.20 \\
Bachelor & 66 & 34.02 \\
Master & 48 & 24.74 \\
Total & 194 & 100 \\
Work Experience & & \\
Less than one year & 18 & 9.28 \\
2-5 year & 109 & 56.19 \\
6-10 year & 32 & 16.49 \\
11-15 year & 27 & 13,92 \\
Above 15 year & 8 & 4.12 \\
\hline Total & 194 & 100 \\
\hline
\end{tabular}

Note. Field survey, 2018.

Above Table shows that $45.88 \%$ respondents are male and $54.12 \%$ respondents are female in the this study similarly $47.42 \%$ respondents are within the age of $20-30$ years, $31.96 \%$ respondents are within the age of $31-40$ years $12.89 \%$ respondents are within the age of 41-50 years and $7.73 \%$ respondents are above 50years. The table also shows that $18.04 \%$ employees are SLC, 23.24\% employees have completed certificate level, 34.02\% employees have bachelor level and $24.74 \%$ employees have master level degree. The Above Table also shows that $9.28 \%$ employees has less than one year work experience $56.19 \%$ employees has 2 5 year work experience, $16.49 \%$ employees has 6-10 year work experience, $13.92 \%$ employees has 11-15 year work experience and $4.12 \%$ employees has more than 15 year work experience. 
Table 2

Most Motivating Factors

\begin{tabular}{lcc}
\hline Motivating factors & Frequency & Percentage (\%) \\
\hline Salary & 58 & 29.90 \\
Good working environment & 46 & 23.71 \\
Freedom to work & 23 & 11.85 \\
Recognition & 18 & 9.28 \\
Job security & 23 & 11.85 \\
Career development and training program & 26 & 13.41 \\
\hline Total & 194 & 100 \\
\hline
\end{tabular}

Note. Field survey, 2018.

Above table 2 shows that 58 employees consider Salary as a most motivating factor, 46 employees think that good working environment is a most motivating factors, 23 employees taken Freedom to work as a motivating factor, Recognition is taken as a motivating factor by 18 employees, 23 employees consider job security as a motivating factor whereas 26 employees taken career development and training program as their motivating factors.

Table 3

Incentives Influence Performance

\begin{tabular}{lrr}
\hline Incentives influence performance & Frequency & Percentage (\%) \\
\hline Yes & 143 & 73.71 \\
No & 51 & 26.29 \\
\hline Total & 194 & 100 \\
\hline
\end{tabular}

Note. Field survey, 2018.

Above table 3 shows that $73.71 \%$ employees think that incentives influence their performance while $26.29 \%$ employees think that others factors influence their performance.

\section{Table 4}

Fair Performance Appraisal System

\begin{tabular}{lll}
\hline Response & Frequency & Percentage (\%) \\
\hline Yes & 125 & 64.43 \\
No & 69 & 35.57 \\
\hline Total & 194 & 100 \\
\hline
\end{tabular}

Note. Field survey, 2018. 
Above Table 4 shows that $64.43 \%$ respondents find that there is fair performance appraisal system in Private Schools of Birgunj Metropolitan city and 35.575 respondents were think that performance appraisal system in is not fair in private schools of birgunj metropolitan city.

\section{Table 5}

Satisfaction Level with Motivation Packages

\begin{tabular}{lrr}
\hline Level & Frequency & Percentage (\%) \\
\hline Satisfied & 104 & 53.61 \\
Average & 90 & 46.39 \\
\hline Total & 194 & 100 \\
\hline
\end{tabular}

Note. Field survey, 2018.

Above table shows that 104 respondents are satisfied with the motivational packages offered by the private schools of Birgunj metropolitan city and 90 respondents are think that motivational packages offered by private schools were not enough.

\section{Table 6}

Monetary vs. Non-Monetary Incentives

\begin{tabular}{lrr}
\hline Incentives & Frequency & Percentage (\%) \\
\hline Monetary & 82 & 42.27 \\
Non-monetary & 68 & 35.05 \\
Both & 44 & 22.68 \\
\hline Total & 194 & 100 \\
\hline
\end{tabular}

Note. Field survey, 2018

Table 6 shows that 82 respondents were happy to enjoy monetary incentives, whereas 68 respondents were enjoying nonmonetary incentives, while 44 respondents feel that both monetary and non-monetary incentives are important for private schools teaches.

\section{Table 7}

Suggested Motivational Package

\begin{tabular}{lrr}
\hline \multicolumn{1}{c}{ Suggested motivational package } & Frequency & Percentage (\%) \\
\hline Promotion on the basis of experience/performance & 80 & 41.24 \\
Job related training & 47 & 24.23 \\
Recognition & 35 & 18.04 \\
Involvement in decision making & 32 & 16.49 \\
\hline Total & 194 & 100 \\
\hline
\end{tabular}

Note. Field survey, 2018. 
Above Table 7 shows that 80 respondents want to enjoy promotion on the basis of experience/performance. 47 respondents want to be promoted on the basis of job-related training and 35 respondents want recognition as motivational package whereas 32 employees like involvement in decision making as motivational package in their private schools.

Figure shows $41.24 \%$ of the respondent want to add promotion on the basis of experience and performance, $24.23 \%$ respondent wish to have job related training as motivational package, $18.04 \%$ respondent want recognition as motivational package and Involvement in decision making taken as motivational package by $16.49 \%$ respondents while they give their best on their job.

\section{Conclusions}

The study concludes that workforce encompasses of both male and female staff, even though majority covers female staff. Most of the employees are in between 20-30 years. It revealed that young generation is attracted towards working in schools. It also shows that majority of the employee has achieved good academic qualification and schools are enjoying by choosing qualified persons to achieve their goals. Schools are not bias on gender matter. Male and female both staffs are equally working in all departments. Majority of the employees have more than 2 year's work experience that is add in the achievement of organizational goals. Socially accepted or reinforced behavior of employees in organizations/schools positively enhance employee's performance in terms of student performance and the overall school performance. The study also shows that employees enjoy the work and most of the employee have more than 2-year experience. Managing human resource is not easy because it differs individually so dealing with different interest, the schools have introduced salary, work recognition, allowance and good working environment as motivating factors. Majority of the school's employee motivating factor is good working environment. The opinion of the Employees of private schools of Birgunj metropolitan city is that performance evaluation system should be fair for all employees working in schools at different level. Employees consider both monetary and non-monetary incentives are equally important to motivate them. As a result of the provided motivational packages most of the employee satisfied and happy to work with schools and have got inner satisfaction. In motivational packages promotion, job related training and work recognition have effects on employee performance. So, employees want to add and improve these motivational packages and broaden the range of motivating factors in future.

\section{Recommendations}

On the basis of the above studies it is recommended that Schools should be encouraged to foster innovation and risk taking, encourage teacher participation in decision making and provide time for collaboration since these are the pillars to success. Academic emphasis, 
artifacts of orderliness, continuous school improvement, teamwork and adaptation to customer's demands should be taken into consideration when school initiate developmental school programs. Basic assumption and culture linkage as well as tight and loose coupling of should provide several approaches to coordinating and directing staff activities to enhance staff performance in private schools. It is good to have young, experience and more educated people in organization that can create more productive environment in programs so management should capitalize these human resources for better environment and quality education. It is quite necessary to make sure that the working environment of the organization is good and does not cause any working discomfort for the employees during the work process so not only monetary incentives but non-monetary incentives should also be taken into consideration by the organization. Human motivation is changeable, not stable so it should be considered in mind that motivational packages like work recognition, promotion and job related training should be managed effectively for the betterment of school and employees.

\section{References}

Acharya, B. S. (2010). Organizational behavior (2nd ed.). Asmita Books Publishers and Distributors P. Ltd.

Adhikari, D. R. (2010). Organizational Behavior (3rd ed.). Buddha Academic Publishers \& Distributors Pvt. Ltd.

Allender, S., Cowburn G., \& Foser, E. (2006). Understanding participation in sports and $\backslash$ physical activity among children adults, 826-836.

Alumode, B. E. (2005). Enrolment patterns and teacher's adequacy in Ebonyi State secondary school. [An unpublished Ph.D thesis], Department of Educational Foundations, Faculty of Education. Ebonyi State University.

Armstrong, M. (2010). Armstrong's handbook of performance management. Kogan Page Limited.

Azoulay P., Graff Zivin, J. S., \& Manso, G. (2010). Incentives and creativity: Evidence from the academic life science. The Journal of Economics 42(3), 527-554.

Chowdhury, M. S. (2007). Enhancing motivation and work performance of the sales people: The impact of supervisors' behavior. African Journal of Business Management, 1(9), 238-243.

Dewhurst, M., Guthridge M., \& Mohr, E. (2009). Motivating people: Getting beyond money. McKinsey\& Company Quarterly.

Griffin, R.W. (2000). Management (5th ed.). AITBS Publisher \& Distributors.

Head, G. M., \& Griffin, R. W. (2009). Managing people and organizations. Biztantra. 
Kalimullah, A. R., Yaghoubi, N. M., \& Moloudi, J. (2010). Survey of relationship between organizational justice and empowerment: A case study. European Journal of Economics, Finance and Administrative Sciences, 24, 165-171

Miner J. B. (2006). Essential theories of motivation and leadership. Prentice Hall of India Private Limited.

Oldham G.R., \& Hackman, J. R. (2010). Not what it was and not what it will be: The future of job design research, Journal of Organizational Behavior 31(2-3), 463-479.

Omebe S. E. (2005). Guidance and counseling: A comprehensive approach. Cheston Agency Ltd.

Osterloh M., \& Frey, B. S. (2002). Successful management by motivation: Balancing intrinsic and extrinsic incentives.

Rutherford. (1990). Physical fitness testing: the effect of rewards and feedback on intrinsic motivation. Physical Educator.

Rynes, S. L., Gerhart, B., \& Minette, K. A. (2004). The importance of pay in employee motivation: Discrepancies between what people say and what they do. Human Resource Management: Published in Cooperation with the School of Business Administration, The University of Michigan and in alliance with the Society of Human Resources Management, 43(4), 381-394.

Khadka, S. (2011). Employee retention in banking industry of Nepal. Singhania University.

Saleem, R., Mahmood, A., \& Mahmood, A. (2010). Effect of work motivation on job satisfaction in mobile telecommunication service organizations of Pakistan. International journal of business and management, 5(11), 213.

Shadare, O. H. (2009). Influence of work motivation leadership effectiveness and time management of employee's performance in some selected industries in Ibadan. Journal of Economics Finance and Administrative Science, 1450-2887 (16), 7-17.

Shanks, N. H. Management and motivation [WWW page] URL www.jblearning.com/catalog/samplefile.aspx $?$ isbn=076373473X\&filename $=3473 X \_C$ H02_4759

William, A. N. (2010). Employee motivation and performance. Mikkeli University of Applied Sciences (Thesis). 